\title{
Soil Mechanics
}

\section{Principles and Practice}

\author{
G. E. Barnes
}

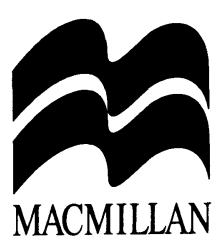


(C) G. E. Barnes 1995

All rights reserved. No reproduction, copy or transmission of this publication may be made without written permission.

No paragraph of this publication may be reproduced, copied or transmitted, save with written permission or in accordance with the provisions of the Copyright, Designs and Patents Act 1988, or under the terms of any licence permitting limited copying issued by the Copyright Licensing Agency, 90 Tottenham Court Road, London W1P 9HE.

Any person who does any unauthorised act in relation to this publication may be liable to criminal prosecution and civil claims for damages.

First published 1995 by

MACMILLAN PRESS LTD

Houndmills, Basingstoke, Hampshire RG21 6XS

and London

Companies and representatives throughout the world

ISBN 978-0-333-59654-8

ISBN 978-1-349-13258-4 (eBook)

DOI 10.1007/978-1-349-13258-4

A catalogue record for this book is available from the British Library.

$\begin{array}{llllllllll}10 & 9 & 8 & 7 & 6 & 5 & 4 & 3 & 2 & 1\end{array}$

04030201009998979695

\section{Acknowledgements}

Extracts from British Standards are reproduced with the permission of BSI. Complete copies can be obtained by post from BSI Sales, Linford Wood, Milton Keynes, MK14 6LE. Tables 13.1 and 13.7 are reproduced with the permission of the Controller of Her Majesty's Stationery Office. Material from ASTM publications is reproduced with their permission. Full versions can be obtained from American Society for Testing and Materials, 1916 Race Street, Philadelphia, Pa. 19103-1187, USA. Figure 12.10 is reproduced with permission from the Boston Society of Civil Engineers Section, American Society of Civil Engineers. The Journal of the Boston Society of Civil Engineers is now known as 'Civil Engineering Practice'. Figures 5.6, 9.7, 9.18, 9.19, 10.9 and 10.10 have been reproduced with permission from the American Society of Civil Engineers. Figures 5.2, 8.19, 8.20, $10.9,10.10,10.11,10.20,12.4,12.17,13.11$ and Table 9.7 have been reproduced with permission from John Wiley and Sons, Inc., New York. Figure 3.15 is reproduced with the permission of McGraw-Hill, Inc. Figure 5.8 is reproduced with the permission of Engineering Publications Office, University of Illinois. Figure 7.13 is reproduced with the permission of The Royal Society and Professor P.W. Rowe. Figure 9.1 is reproduced with the permission of Transportation Research Board, National Research Council, Washington, D.C. Figure 9.5 is reproduced with the permission of $\mathrm{Mr}$. F.G. Butler. Figures $10.15,10.16,10.18$ and 10.19 are reproduced with the permission of $\mathrm{Dr} \mathrm{T}$. Whitaker.

The author wishes to record his thanks to all of the other organisations who have granted permission to use material from their sources. 


\section{Contents}

Preface

List of symbols

Note on units

\section{Soil Formation and Nature}

\author{
Soil Formation \\ Introduction \\ Man-made soils \\ Contaminated and polluted soils \\ Naturally-occurring soils \\ In situ soils - weathered rocks \\ In situ soils - peat \\ Water-borne soils \\ Glacial deposits \\ Wind-blown soils
}

\section{Soil Particles}

Nature of particles

Clay minerals

\section{Soil Structure \\ Introduction \\ Granular soils \\ Relative density \\ Cohesive soils}

\section{Soil Description and Classification}

Soil Description
Introduction
Classification
Made Ground
Topsoil
Clay
Silt
Sand and gravel
Cobbles and boulders
Peat and organic soils
Types of description

viii
ix
xiii

Soil Classification

Introduction

18

Particle density

19

Particle shape

Particle size distribution $\quad 20$

Density 22

Moisture content 24

Consistency and Atterberg limits 25

Plasticity chart $\quad 27$

Activity 28

Shrinkage limit 28

Soil model $\quad 29$

Worked Examples $\quad 32$

Exercises $\quad 35$

\section{Permeability and Seepage}

\section{Permeability}

5 Introduction $\quad 36$

Groundwater $\quad 36$

Flow problems $\quad 36$

8 Stability problems $\quad 37$

$8 \quad$ Soil voids 38

9 Pressure and head $\quad 39$

10 Darcy's Law 39

Effect of temperature $\quad 40$

Empirical correlations for $k \quad 40$

Layered soils $\quad 42$

Laboratory tests $\quad 43$

Borehole tests 46

Pumping tests 51

\section{Seepage}

Seepage theory 51

Flow nets 53

Flow net construction $\quad 54$

Seepage quantities 57

Total head, elevation head and pressure head $\quad 57$

Pore pressure and uplift pressure $\quad 58$

Seepage force $\quad 58$

Quick conditions and boiling $\quad 58$ 
Piping adjacent to sheet piling

Seepage through earth dams

Seepage through flood banks, levées

Worked Examples

Exercises

\section{Effective Stress and Pore Pressure}

Total stress

Pore pressures below the water table

Effective stress

Stress history

Normally consolidated clay

Overconsolidated clay

Overconsolidation ratio

Desiccated crust

Present state of stress in the ground

Mohr's circle of stress

Earth pressure at rest

Changes in stress due to engineering works

Pore pressure parameters

Capillary rise above the water table

Effective stresses above the water table

Worked Examples

Exercises
8
Worked Examples

100

103

\section{Compressibility and Consolidation}

Compressibility

Introduction

Void ratio/effective stress plot

Reloading curves

Preconsolidation pressure

Effect of sampling disturbance

In situ curve for normally consolidated clay

In situ curve for overconsolidated clay

Isotropic compression

Anisotropic compression

\section{Consolidation}

Terzaghi theory of one-dimensional

consolidation

Oedometer test

Coefficient of consolidation

Rowe consolidation cell

Two and three-dimensional consolidation

Radial consolidation for vertical drains

Worked Examples

Exercises
109

111

104

104

105

105

106

106

106

107

108

114

116

118

119

122

128

\section{Contact Pressure and Stress Distribution}

$\begin{array}{lr}\text { Contact pressure } & \\ \text { Introduction } & 91 \\ \text { Uniform loading } & 91 \\ \text { Point loading } & 92 \\ \text { Stress distribution } & \\ \text { Introduction } & 92 \\ \text { Stresses beneath point load and line load } & 92 \\ \text { Assumptions } & 94 \\ \text { Stresses beneath uniformly loaded areas } & 94 \\ \text { Bulbs of pressure } & 94 \\ \text { Stresses beneath a flexible rectangle } & 97 \\ \text { Principle of superposition } & 97 \\ \text { Stresses beneath flexible area of any shape } & 97 \\ \text { Stresses beneath a flexible rectangle - finite soil } \\ \text { thickness } & 99 \\ \text { Stresses beneath a rigid rectangle } & 99\end{array}$

\section{Shear Strength}

\section{General}

Introduction

130

Effects of strain $\quad 130$

Failure criterion $\quad 132$

Stress paths 133

Effects of drainage $\quad 133$

Test procedures $\quad 136$

\section{Shear strength of sand}

Stress-strain behaviour $\quad 139$

Shear box test $\quad 140$

Effect of packing and particle nature $\quad 141$

Constant volume condition 142

Shear strength of clay

Effect of sampling

Undrained cohesion, $c_{\mathrm{u}} \quad 143$

Unconfined compression test 143 
Vane test

143

Triaxial test

145

Triaxial unconsolidated undrained test (UU)

Effect of clay content and mineralogy

Partially saturated clays

Fissured clays

Variation with depth

Frictional characteristics

Test procedures

Triaxial consolidated undrained test (CU)

Triaxial consolidated drained test (CD)

\section{Critical state theory}

Residual strength

Worked Examples

Exercises

\section{Shallow Foundations - Stability}

\section{General}

Introduction

Spread foundations

Design requirements

Types of shallow foundation

Strip foundations

Pad foundations

Raft foundations

Depth of foundations

\section{Bearing capacity}

Modes of failure

Bearing capacity - vertical loads only

Shape and depth factors

Bearing capacity - overturning

Eccentric loading

Inclined loading

Different soil strength cases

Effect of water table

Net ultimate bearing capacity

Factor of safety

Effect of compressibility of soil

Sliding

\section{Allowable bearing pressure of sand}

Settlement limit

Allowable bearing pressure

146

148

148

148

149

151

151

151

153

153

159

161

166

176

176

178

178

178

179

181

181

182

182

183

184
Worked Examples

187

Exercises

191

9 Shallow Foundations - Settlements

Introduction

Clays - immediate settlement

General method

Principle of superposition

Principle of layering

192

195

195

Depth correction

195

Average settlement

195

Modulus increasing with depth

195

Effect of local yielding

198

Clays - consolidation settlement

Compression index $C_{\mathrm{c}}$ method

198

Oedometer or $m_{\mathrm{v}}$ method

Clays - total settlement

Skempton-Bjerrum method

200

Elastic drained method

201

Estimation of drained modulus

203

Secondary compression

Introduction

203

General method 204

Estimation of $C_{\alpha}$ or $\varepsilon_{\alpha}$ values

204

Sands

Introduction

205

Methods of estimating settlements

206

Schmertmann's method

206

Burland and Burbridge's method

207

Permissible settlements

Introduction

Definitions of ground and foundation

movement

Criteria for movements

Routine settlement limits

213

Worked Examples

218 


\section{Pile Foundations}

\section{Single piles}

Introduction

Loading conditions

Types of pile

Design of single piles

Load capacity of single piles

Bored piles in clay

End bearing resistance

Adhesion

Driven piles in clay

End bearing resistance

Adhesion

Effective stress approach for adhesion

Driven piles in sand

Effects of installation

End bearing resistance

Critical depth

Skin friction

Bored piles in sand

Factor of safety

Pile groups

Pile spacing

Stressed zone

Load variation

Efficiency

Ultimate capacity

Settlement ratio

Settlement of pile groups

Worked Examples

Exercises

\section{Lateral Earth Pressure and Design of Retaining Structures}

\author{
Lateral earth pressures \\ Introduction \\ Effect of horizontal movements \\ Effect of wall flexibility and propping
}

Effect of wall friction 243

Coulomb theory - active thrust 243

Coulomb theory - passive thrust 245

220

220

220

221

221

222

222

223

223

225

226

226

226

227

229

229

230

230

230

231

232

233

234

236

239

$\begin{array}{lll} & \text { Reinforced earth } & \\ & \text { Introduction } & 263 \\ & \text { Effects of reinforcement } & 263 \\ & \text { Internal stability } & 263 \\ & \text { External stability } & 265 \\ & \text { Worked Examples } & 266 \\ 240 & \text { Exercises } & 273 \\ 240 & & \\ 242 & & \end{array}$




\section{Slope Stability}

\author{
General \\ Introduction \\ Types of mass movement \\ Natural slopes \\ Artificial slopes or earthworks \\ Short-term and long-term conditions

\section{Methods of analysis} \\ Plane translational slide \\ Circular arc analysis - undrained conditon \\ Tension crack \\ Undrained analysis - stability charts \\ Effective stress analysis - method of slices \\ Fellenius method \\ Bishop simplified method \\ Pore pressure ratio $r_{\mathrm{u}}$ \\ Effective stress analysis - stability \\ coefficients \\ Submerged slopes \\ Rapid drawdown \\ Non-circular slip surfaces - Janbu method \\ Wedge method - single plane \\ Wedge method - multi-plane \\ Factor of safety \\ Worked Examples \\ Exercises
}

\section{Earthworks and Soil Compaction}

\author{
Earthworks \\ Introduction \\ Construction plant \\ Purpose and types of materials \\ Material requirements \\ Acceptability of fill \\ Acceptability of granular soils \\ Acceptability of cohesive soils \\ Efficiency of earthmoving \\ Material problems \\ Softening \\ Bulking
}

304

304

306

306

307

309

309

310

311
Soil compaction

Introduction

313

Factors affecting compaction

\section{Laboratory compaction}

Introduction

Laboratory tests

Air voids lines

Correction for stone content 321

Worked Examples

322

Exercises

\section{Site Investigation}

$\begin{array}{ll}\text { Site investigation } & \\ \text { Introduction } & 328 \\ \text { Stages of investigation } & 328 \\ \text { Desk study } & 328 \\ \text { Site reconnaissance } & 329\end{array}$

\section{Ground investigation}

Extent of the ground investigation 329

Depth of exploration $\quad 330$

Choice of method of investigation $\quad 330$

Methods of ground investigation 331

Undisturbed sampling - sampling quality $\quad 335$

Types of samples $\quad 335$

Methods of in situ testing $\quad 339$

Groundwater observations $\quad 342$

Investigation of contaminated land $\quad 345$
Site investigation reports

Introduction

345

Factual report

346

Interpretative report

348

References $\quad 352$

Index
Answers to exercises $\quad 350$ 


\section{Preface}

The main aims of this book are to provide an understanding of the nature of soil, an appreciation of soil behaviour and a concise and clear presentation of the basic principles of soil mechanics.

The subject of soil mechanics attempts to provide a framework for understanding the behaviour of the ground by considering the principles which apply to soils. The geotechnical engineer must then use judgement to determine how to apply these principles in real situations.

It is often said that soil mechanics is a 'black art' because these principles may not apply universally, and there is a considerable amount of empirical knowledge which has been built up over the years but which still serves the engineer well. This is also probably a result of trying to apply a purely scientific approach to a material which has not been controlled during its manufacture by human interference. Instead the ground is a natural material, variable, unique, not fully understood and sometimes surprising in its behaviour.

The book is intended as a main text for undergraduate civil and ground engineering students to provide the basic principles and to illustrate how, why and with what limitations these principles can be applied in practice. It is also intended to be retained by these students when they become practitioners and for professionals already in practice as a reference source providing guidance and information for the solution of real geotechnical problems.

It is assumed that the reader will have a basic understanding of mathematics and science and a good understanding of applied mechanics. In civil engineering undergraduate degree courses there is often insufficient emphasis on the need to provide a sound knowledge of geology and, in particular, the superficial geology, in other words, the soils! This material too often gets in the way for many geologists who are mainly interested in the rocks.
A good geotechnical engineer will have a knowledge of mathematics, science and be proficient with soil mechanics but a knowledge of geology, soil profiles and groundwater conditions is fundamental to the application of soil mechanics. For this reason the book aims to consider soil mechanics with more emphasis on its application in the ground and less emphasis on the behaviour of soils in the unnatural environment of the laboratory.

The book contains a range of worked examples to assist the learning of the subject and illustrate the applications of the various analytical approaches. To consolidate this understanding, problem exercises have been included for students to attempt themselves.

I am most grateful to all those researchers, writers and practising engineers who have investigated the subject and collected information over the last seventy years or so, without whom no standard text-book could be written. In particular, I wish to record my thanks to those publishers, organisations and individuals who have granted permission to use material from their publications.

I wish to express my gratitude to Dr Bob Saxton from Plymouth University for reviewing the draft manuscript and making valuable comments. I wish to thank Professor Clive Melbourne, Head of School of Civil Engineering at Bolton Institute for his support and encouragement. Thanks are are also due to Miss Joanne Carney for typing the draft manuscript. Finally, my sincere thanks go to my wife, Linda, for her support and understanding during the preparation of the book. 


\section{List of symbols}

A Activity

A Area

$A^{\prime} \quad$ Effective area

A Pore pressure parameter

$A_{\mathrm{c}} \quad$ Ash content

$A_{\mathrm{b}} \quad$ Pile base area

$A_{\mathrm{f}} \quad$ Pore pressure parameter at failure

$A_{\mathrm{r}} \quad$ Area ratio

$A_{\mathrm{s}} \quad$ Pile shaft area

$A_{\mathrm{v}} \quad$ Air voids content

$a \quad$ Slope stability coefficient

$B \quad \%$ of particles passing maximum size

$B$ Width of foundation

$B$ Pore pressure parameter

$\bar{B} \quad$ Pore pressure parameter

$B^{\prime} \quad$ Effective width

$b \quad$ Slope stability coefficient

$\mathrm{C}_{\mathrm{N}} \quad$ Correction for overburden pressure

$\mathrm{C}_{\mathrm{w}} \quad$ Correction for water table

$C_{\mathrm{c}} \quad$ Compression index

$C_{\text {c }} \quad$ Coefficient of curvature

$C_{\alpha} \quad$ Coefficient of secondary compression

$C_{\mathrm{s}} \quad$ Soil skeleton compressibility

$C_{\mathrm{s}} \quad$ Swelling index

$C_{\mathrm{w}} \quad$ Compressibility of pore water

$C D$ Consolidated drained

$C U$ Consolidated undrained

Cl Consistency index

CSL Critical state line

$c_{\mathrm{a}} \quad$ Adhesion

$c_{\mathrm{b}} \quad$ Adhesion at underside of foundation

$c_{\mathrm{r}} \quad$ Remoulded undrained cohesion

$c_{\mathrm{u}} \quad$ Undrained cohesion

$c_{\mathrm{v}} \quad$ Coefficient of consolidation, vertical direction

$c_{\mathrm{H}} \quad$ Coefficient of consolidation, horizontal direction

$c_{\mathrm{w}} \quad$ Adhesion between soil and wall

$c^{\prime} \quad$ Cohesion in effective stress terms

$D$ Depth of foundation

$D$ Depth factor of slip circle

$d$ Diameter, depth of penetration, particle size

$d \quad$ Length of drainage path

$d_{0} \quad$ Initial depth of embedment
$D_{\mathrm{r}} \quad$ Relative density

$E^{\prime} \quad$ Young's modulus in terms of effective stress (drained condition)

$E_{\mathrm{p}} \quad$ Pressuremeter modulus

$E_{\mathrm{u}} \quad$ Young's modulus in terms of total stress (undrained condition)

$E \quad$ Lateral force on side of slice

ESP Effective stress path

$e \quad$ Eccentricity

$e \quad$ Void ratio

$e_{0} \quad$ Initial void ratio

$e_{\mathrm{f}} \quad$ Final void ratio

$e_{\max } \quad$ Void ratio at loosest state

$e_{\min } \quad$ Void ratio at densest state

$F \quad$ Factor of safety, length factor

$F \quad$ Force

$F_{\mathrm{d}} \quad$ Enlargement factor

$F_{\mathrm{B}} \quad$ Correction for roughness

$F_{\mathrm{D}} \quad$ Correction for depth of embedment

$f \quad$ Shape factor or intake factor

$f_{0} \quad$ Slope stability correction factor

$f_{\mathrm{s}} \quad$ Skin friction, sleeve friction

$f_{\mathrm{s}} \quad$ Shape factor

$f_{\mathrm{t}} \quad$ Correction for time

$f_{t} \quad$ Permissible tensile strength of reinforcement

$f_{\mathrm{y}} \quad$ Yield factor

$f_{1} \quad$ Thickness factor

$G \quad$ Shear modulus

$G_{\mathrm{s}} \quad$ Specific gravity of particles

$g$ Gravitational acceleration $\left(9.81 \mathrm{~m} / \mathrm{s}^{2}\right)$

$g$ Soil constant for the Hvorslev surface

$H$ Height, thickness, horizontal force

$H_{\text {c }} \quad$ Constant head above the water table

$H_{0} \quad$ Initial head above the water table

$H_{\mathrm{t}} \quad$ Head at time $t$

$h \quad$ Head difference

$h_{\mathrm{c}} \quad$ Capillary rise

$h_{\mathrm{m}} \quad$ Mean head

$h_{\mathrm{p}} \quad$ Pressure head

$h_{\mathrm{s}} \quad$ Fully saturated capillary zone

$h_{\mathrm{w}} \quad$ Depth to water table

$h_{7} \quad$ Elevation or position head

$I$ Influence value or factor 
ICL Isotropic normal consolidation line

$I_{\mathrm{c}} \quad$ Compressibility index

$I_{\mathrm{p}} \quad$ Plasticity index (or $P I$ )

$I_{2} \quad$ Strain influence factor

$i \quad$ Hydraulic gradient

$i_{\mathrm{c}} \quad$ Critical hydraulic gradient

$i_{\mathrm{e}} \quad$ Exit hydraulic gradient

$i_{\mathrm{m}} \quad$ Mean hydraulic gradient

$J$ Seepage force

$K \quad$ Absolute or specific permeability

$K_{0} \quad$ Coefficient of earth pressure at rest

$K_{0} C L K_{0}$ normal consolidation line

$K_{\mathrm{a}} \quad$ Coefficient of active earth pressure

$K_{\text {ac }} \quad$ Earth pressure coefficient

$K_{\mathrm{p}} \quad$ Coefficient of passive pressure

$K_{\mathrm{pc}} \quad$ Earth pressure coefficient

$K_{\mathrm{s}} \quad$ Coefficient of horizontal pressure

$k \quad$ Coefficient of permeability

$k \quad$ Coefficient for modulus increasing with depth

$L, l$ Length, lever arm

$L^{\prime} \quad$ Effective length

$L L \quad$ Liquid limit

$L I \quad$ Liquidity index

M Moment

$M \quad$ Gradient of the critical state line on $p^{\prime}-q^{\prime}$ plot

MCV Moisture condition value

$m$ Mass

$m \quad$ Slope stability coefficient

$m_{\mathrm{v}} \quad$ Coefficient of volume compressibility

$N \quad$ Normal total force

$N \quad$ Stability number

$N \quad$ Specific volume at $p^{\prime}=1.0 \mathrm{kN} / \mathrm{m}^{2}$ on $I C L$

$N \quad$ Standard penetration test result, No. of blows

$N^{\prime} \quad$ Corrected SPT value

$N^{\prime} \quad$ Normal effective force

$N_{\mathrm{c}} \quad$ Bearing capacity factor

$N_{\mathrm{q}} \quad$ Bearing capacity factor

$N_{\gamma} \quad$ Bearing capacity factor

NC Normally consolidated

$N_{0} \quad$ Specific volume at $p^{\prime}=1.0 \mathrm{kN} / \mathrm{m}^{2}$ on $K_{0} C L$

$N_{\text {s }} \quad$ Stability number

$n \quad$ Porosity, number of piles

$n \quad$ Slope stability coefficient

$n \quad$ Ratio $R / r_{\mathrm{d}}$

$n_{\mathrm{d}} \quad$ Number of equipotential drops

$n_{\mathrm{f}} \quad$ Number of flow paths

$O_{\text {c }} \quad$ Organic content

OC Overconsolidated
OCR Overconsolidation ratio

$P L \quad$ Plastic limit

$P I \quad$ Plasticity index (or $I_{\mathrm{p}}$ )

$P \quad$ Force

$P_{\mathrm{a}} \quad$ Resultant active thrust or force

$P_{\mathrm{p}} \quad$ Resultant passive thrust or force

$P_{\text {an }} \quad$ Normal component of active thrust

$P_{\mathrm{pn}} \quad$ Normal component of passive thrust

$P_{\mathrm{w}} \quad$ Horizontal water thrust

$p \quad$ Pressure, contact pressure

$p \quad$ Stress path parameter (Total stress)

$p^{\prime} \quad$ Stress path parameter (Effective stress)

$p_{c}{ }^{\prime} \quad$ Preconsolidation pressure

$p_{\mathrm{c}}{ }^{\prime} \quad$ Initial isotropic stress

$p_{0}^{\prime} \quad$ Present overburden pressure (Effective stress)

$p_{0} \quad$ Total overburden pressure

$Q \quad$ Steady state quantity of flow

$Q_{\text {ult }} \quad$ Ultimate load

$Q_{\text {s }} \quad$ Ultimate shaft load

$Q_{\text {b }} \quad$ Ultimate base load

$Q \quad$ Line load surcharge

$q \quad$ Flow rate

$q \quad$ Uniform surcharge

$q \quad$ Stress path parameter (Total stress)

$q^{\prime} \quad$ Stress path parameter (Effective stress)

$q_{\text {a }} \quad$ Allowable bearing pressure

$q_{\text {app }} \quad$ Applied pressure (or $q$ )

$q_{\mathrm{b}} \quad$ End bearing resistance

$q_{\mathrm{c}} \quad$ Cone penetration resistance

$q_{\max }$ Maximum bearing pressure

$q_{\mathrm{s}} \quad$ Safe bearing capacity

$q_{\text {utt }} \quad$ Ultimate bearing capacity

$R \quad$ Resultant force, distance

$R \quad$ Dial gauge reading

$R \quad$ Radius of influence of drain

$R_{\mathrm{f}} \quad$ Friction ratio

$R_{\mathrm{s}} \quad$ Pile group settlement ratio

$R_{3}, R_{\mathrm{t}}$ Time correction factors

$R_{\mathrm{T}} \quad$ Correction for temperature

$r$ Radial distance, or radius

$r_{\mathrm{d}} \quad$ Radius of well or drain

$r_{\mathrm{u}} \quad$ Pore pressure ratio

$S_{\mathrm{r}} \quad$ Degree of saturation

$S L \quad$ Shrinkage limit

$s \quad$ Spacing of drains, spacing of piles, anchors

$s \quad$ Stress path parameter (Total stress)

$s^{\prime} \quad$ Stress path parameter (Effective stress)

$T \quad$ Shear force, surface tension force, torque 
$T \quad$ Tensile force in reinforcement

TSP Total stress path

$T_{\mathrm{v}} \quad$ Time factor for one-dimensional consolidation

$T_{\mathrm{R}} \quad$ Time factor for radial consolidation

$t$ Time

$t \quad$ Stress path parameter (Total stress)

$t^{\prime} \quad$ Stress path parameter (Effective stress)

$U \quad$ Water force

$U, U_{\mathrm{c}}$ Uniformity coefficent

$U_{\mathrm{c}} \quad$ Combined or overall degree of consolidation

$U_{\mathrm{R}} \quad$ Degree of radial consolidation

$U_{\mathrm{v}} \quad$ Degree of one-dimensional consolidation

$\overline{U_{\mathrm{v}}} \quad$ Average degree of consolidation

$U U$ Unconsolidated undrained

$u \quad$ Horizontal displacement

$u_{\mathrm{a}} \quad$ Pore air pressure

$u_{\mathrm{w}} \quad$ Pore water pressure

$V \quad$ Volume

$V_{\text {a }} \quad$ Volume of air

$V_{0} \quad$ Initial volume

$V_{\mathrm{s}} \quad$ Volume of solids

$V_{\mathrm{T}} \quad$ Total vertical laod

$V_{\mathrm{v}} \quad$ Volume of voids

$V_{\mathrm{w}} \quad$ Volume of water

$v \quad$ Velocity

$v \quad$ Specific volume

$v_{\kappa} \quad$ Specific volume on isotropic swelling line at $p^{\prime}=1.0 \mathrm{kN} / \mathrm{m}^{2}$

$v_{\kappa(1)} \quad$ Specific volume on anisotropic swelling line at $p^{\prime}=1.0 \mathrm{kN} / \mathrm{m}^{2}$

$v_{\mathrm{s}} \quad$ Seepage velocity

$w \quad$ Water content or moisture content

$w_{\mathrm{c}} \quad$ Saturation moisture content of particles

$w_{\mathrm{c}} \quad$ Equivalent moisture content

$W \quad$ Weight

$W_{\mathrm{p}} \quad$ Weight of pile

$W_{\text {t }} \quad$ Total weight

$W_{\mathrm{w}} \quad$ Weight of water

$X \quad$ Shear force on side of slice

$x, y, z$ Coordinate axes

$Z \quad$ Dimensionless depth

$Z_{1} \quad$ Depth of influence

$z \quad$ Depth

$z_{\text {a }} \quad$ Height above the water table

$z_{c} \quad$ Critical depth

$z_{c} \quad$ Depth of tension crack

$z_{0} \quad$ Depth of negative active earth pressure

$\alpha \quad$ Angle, angular strain $\alpha \quad$ Shaft adhesion factor

$\alpha_{\mathrm{F}} \quad$ Settlement interaction factor

$\alpha_{\mathrm{p}} \quad$ Peak adhesion factor

$\beta \quad$ Angle, relative rotation

$\beta \quad$ Skin friction factor

$\chi \quad$ Proportion of cross-section occupied by water

$\delta \quad$ Angle of wall friction, base sliding, piles

$\Delta$ delta, change in, increment of

$\Delta \quad$ Relative deflection

$\delta \rho \quad$ Differential settlement

$\delta \rho_{\mathrm{h}} \quad$ Differential heave

$\varepsilon_{\alpha} \quad$ Coefficient of secondary compression

$\Phi$ Potential function

$\phi \quad$ Friction angle

$\phi_{1} \quad \phi$ before pile installation

$\phi_{\mathrm{u}} \quad$ Angle of failure envelope, undrained condition

$\phi_{\mathrm{cv}} \quad \phi$ at constant volume

$\phi_{\mu} \quad$ Particle-particle friction angle

$\phi_{\mathrm{m}} \quad$ Mobilised friction angle

$\phi_{\mathrm{r}} \quad \phi$ at residual strength

$\Gamma \quad$ Specific volume at $p^{\prime}=1.0 \mathrm{kN} / \mathrm{m}^{2}$ on $C S L$

$\gamma \quad$ Unit weight

$\gamma_{b} \quad$ Bulk unit weight

$\gamma_{u} \quad$ Dry unit weight

$\gamma_{\min }$ Dry unit weight in loosest state

$\gamma_{\max }$ Dry unit weight in densest state

$\gamma_{\text {sat }} \quad$ Saturated unit weight

$\gamma_{\text {sub }} \quad$ Submerged unit weight

$\gamma_{w} \quad$ Unit weight of water

$\eta \quad$ Efficiency, viscosity of fluid

$\kappa \quad$ Slope of overconsolidation line

$\lambda$ Slope of normal consolidation line

$\lambda \quad$ Pile adhesion coefficient

$\theta$ Rotation, inclination of a plane

$\mu \quad$ Interparticle friction

$\mu \quad$ Vane correction factor

$\mu \quad$ Correction for consolidation settlement

$\mu_{1} \quad$ Influence factor

$\mu_{0} \quad$ Correction for depth

$\mu_{\mathrm{r}} \quad$ Correction for rigidity

$v \quad$ Poisson' ratio

$\rho \quad$ Mass density

$\rho_{\mathrm{b}} \quad$ Bulk density

$\rho_{\mathrm{d}} \quad$ Dry density

$\rho_{\mathrm{f}} \quad$ Fluid density

$\rho_{\mathrm{s}} \quad$ Particle density

$\rho_{\mathrm{w}} \quad$ Density of water 
$\rho_{\text {all }} \quad$ Allowable settlement

$\rho_{\mathrm{i}} \quad$ Immediate settlement

$\rho_{\mathrm{c}} \quad$ Consolidation settlement

$\rho_{\mathrm{h}} \quad$ Heave

$\rho_{\mathrm{s}} \quad$ Secondary settlement

$\rho_{\mathrm{t}} \quad$ Consolidation settlement at time $t$

$\rho_{\mathrm{T}} \quad$ Total settlement

$\rho_{\mathrm{y}} \quad$ Immediate settlement including yield

$\sigma \quad$ Total stress

$\sigma_{\mathrm{N}} \quad$ Normal total stress

$\sigma^{\prime} \quad$ Effective stress

$\sigma_{\mathrm{N}}{ }^{\prime} \quad$ Normal effective stress

$\sigma_{\mathrm{m}} \quad$ Mean stress

$\sigma_{1}, \sigma_{2}, \sigma_{3}$ Major, intermediate and minor principal total stresses

$\sigma_{1}{ }^{\prime}, \sigma_{2}{ }^{\prime}, \sigma_{3}{ }^{\prime}$ Major, intermediate and minor principal effective stresses

$\sigma_{\mathrm{H}}, \sigma_{\mathrm{H}}{ }^{\prime} \quad$ Total and effective horizontal stresses

$\sigma_{\mathrm{v}}, \sigma_{\mathrm{v}}{ }^{\prime} \quad$ Total and effective vertical stresses

$\tau \quad$ Shear stress

$\tau_{\mathrm{y}} \quad$ Yield stress

$\omega \quad$ Tilt, correction for strength of fissured clays

$\Psi \quad$ Flow function 


\section{SI Units}

The International System of units (SI) has been used throughout in this book. A complete guide to the system appears in ASTM E-380 published by the American Society for Testing and Materials. The following is a brief summary of the main units.

The base units used in soil mechanics are

$\begin{array}{ccc}\text { Quantity } & \text { Unit } & \text { Symbol } \\ \text { length } & \text { metre } & \mathrm{m} \\ \text { mass } & \text { kilogram } & \mathrm{kg} \\ \text { time } & \text { second } & \mathrm{s}\end{array}$

Other commonly used units are:

for length:

$$
\begin{gathered}
\text { micron }(\mu \mathrm{m}) \\
\text { millimetre }(\mathrm{mm})
\end{gathered}
$$

for mass:

$$
\begin{gathered}
\text { gram }(\mathrm{g}) \\
\text { megagram }(\mathrm{Mg})
\end{gathered}
$$$$
1 \mathrm{Mg}=1000 \mathrm{~kg}=1 \text { tonne or } 1 \text { metric ton }
$$

for time:

$$
\begin{gathered}
\text { minutes (min) } \\
\text { hours, days, weeks, years }
\end{gathered}
$$

\section{Mass, force and weight}

Mass represents the quantity of matter in a body and this is independent of the gravitational force. Weight represents the gravitational force acting on a mass.

Unit force $(1 \mathrm{~N})$ imparts unit acceleration $\left(1 \mathrm{~m} / \mathrm{s}^{2}\right)$ to unit mass $(1 \mathrm{~kg})$. Newton's Law gives

$$
\text { Weight }=\text { mass } \times \text { gravitational constant }
$$

The acceleration due to gravity on the earth's surface $(g)$ is usually taken as $9.81 \mathrm{~m} / \mathrm{s}^{2}$ so on the earth's surface $1 \mathrm{~kg}$ mass gives a force of $9.81 \mathrm{~N}$.

The unit of force is the newton $(\mathrm{N})$ with multiples of

$$
\begin{aligned}
& \text { kilonewton }(\mathrm{kN})=1000 \mathrm{~N} \\
& \text { meganewton }(\mathrm{MN})=10^{6} \mathrm{~N}
\end{aligned}
$$

Measuring scales or balances in a laboratory respond to force but give a measurement in grams or $\mathrm{kg}$, in other words, in mass terms.

\section{Stress and pressure}

These have units of force per unit area $\left(\mathrm{N} / \mathrm{m}^{2}\right)$. The SI unit is the pascal $(\mathrm{Pa})$.

$$
\begin{aligned}
1 \mathrm{~N} / \mathrm{m}^{2} & =1 \mathrm{~Pa} \\
1 \mathrm{kN} / \mathrm{m}^{2} & =1 \mathrm{kPa}
\end{aligned}
$$

(kilopascal or kilonewton per square metre)

$1 \mathrm{MN} / \mathrm{m}^{2}=1 \mathrm{MPa}$

\section{Density and unit weight}

Density is the amount of mass in a given volume and is best described as mass density $(\rho)$. The SI unit is kilogram per cubic metre $\left(\mathrm{kg} / \mathrm{m}^{3}\right)$. Other units are megagram per cubic metre $\left(\mathrm{Mg} / \mathrm{m}^{3}\right)$.

Density is commonly used in soil mechanics because laboratory balances give a measure of mass.

Unit weight $(\gamma)$ is the force within a unit volume where

$$
\gamma=\rho g
$$

The common unit for unit weight is kilonewton per cubic metre $\left(\mathrm{kN} / \mathrm{m}^{3}\right)$ or sometimes $\mathrm{MN} / \mathrm{m}^{3}$.

Unit weight is a useful term in soil mechanics since it gives vertical stress directly when multiplied by the depth. 


\section{Other titles of interest to Civil Engineers}

Understanding Hydraulics

Les Hamill

Prestressed Concrete Design by Computer

R. Hulse and W. H. Mosley

Reinforced Concrete Design by Computer

R. Hulse and W. H. Mosley

Reinforced Concrete Design, Fourth Edition

W. H. Mosley and J. H. Bungey

Civil Engineering Contract Administration and Control, Second Edition

I. H. Seeley.

Civil Engineering Quantities, Fifth Edition

I. H. Seeley

Understanding Structures

Derek Seward

Fundamental Structural Analysis

W. J. Spencer

Surveying for Engineers, Third Edition

J. Uren and W. F. Price

Engineering Hydrology, Fourth Edition

E. M. Wilson

Civil Engineering Materials, Fifth Edition

Edited by N. Jackson and R. K. Dhir

Timber - Structure, Properties, Conversion and Use, Seventh Edition

H. E. Desch and J. M. Dinwoodie

Highway Traffic Analysis and Design

R. J. Salter and N. B. Hounsell

Plastic Methods for Steel and Concrete Structures, Second Edition

S. S. J. Moy 